\title{
Religious Fundamentalism, Satisfaction with Life and Posttraumatic Stress Symptoms Intensity in a Polish Sample of People Living with HIV/AIDS
}

\author{
Włodzimierz Oniszczenko ${ }^{1}$ (D) Marcin Rzeszutek ${ }^{1}$ - Ewa Firląg- \\ Burkacka $^{2}$
}

Published online: 7 April 2018

(C) The Author(s) 2018

\begin{abstract}
We investigated the relationship between religious fundamentalism, satisfaction with life and the intensity of posttraumatic stress symptoms in people living with HIV/ AIDS. The study was conducted on 283 adults, including 242 HIV-positive patients and 41 individuals with AIDS, aged from 20 to 74 . Religious fundamentalism was positively correlated with age and posttraumatic stress symptoms intensity. Negative correlation between satisfaction with life and posttraumatic stress intensity was also found. Religious fundamentalism and satisfaction with life accounted for $34 \%$ of the variance in posttraumatic stress symptoms intensity. The level of patients' education mediated the relationship between religious fundamentalism and the posttraumatic stress symptoms intensity.
\end{abstract}

Keywords Trauma $\cdot$ Religious fundamentalism $\cdot$ Satisfaction with life $\cdot$ HIV/AIDS

\section{Introduction}

HIV infection is a serious social and medical problem. Thanks to the effectiveness of antiretroviral therapy, HIV infection has become a chronic disease (Deeks et al. 2013). People living with HIV (PLWH) as well as people living with HIV/AIDS (PLWHA) may experience multiple forms of stigma, all of which can negatively impact their health, quality of life, social support and well-being (Logie and Gadalla 2009; Slater et al. 2015). In addition, HIV-positive individuals may suffer from many psychiatric disorders such as anxiety and depression (Kee et al. 2015; Robertson et al. 2014), sleep disturbance (Leyro et al. 2014), substance abuse (Chander et al. 2006) and HIV-related fatigue (Barroso et al. 2010).

Włodzimierz Oniszczenko

wlodek@psych.uw.edu.pl

1 Faculty of Psychology, University of Warsaw, Stawki 5/7, 00-183 Warsaw, Poland

2 Warsaw's Hospital for Infectious Diseases, Warsaw, Poland 
PLWHA and PLWH report high rates of exposure to past or current traumatic events and high levels of posttraumatic stress symptoms (PTSSs). Several other studies suggest three major sources of posttraumatic stress in HIV-positive individuals: psychosocial trauma prior to HIV infection (e.g., childhood abuse, rape, physical assault, partner-inflicted violence) (LeGrand et al. 2015), receiving a diagnosis of the presence of HIV and the related perceived threat to life and cumbersome treatment (Martin and Kagee 2011) and the stigmatization of HIV-positive individuals (Bogart et al. 2011; Breet et al. 2014; Ye et al. 2015).

The presence of health and mental health problems and PTSSs may influence psychological well-being, including satisfaction with life, in both PLWH and PLWHA. Oberjé et al. (2015) showed that environmental well-being (i.e., satisfaction with the conditions and safety of one's living place) and mental health serve as main predictors of subjective well-being (SWB) in HIV-positive individuals, while physical health, social well-being and financial well-being explain SWB to a lesser extent. Satisfaction with life is the cognitive aspect of SWB that refers to a conscious cognitive judgment of one's life. Satisfaction with life reflects the degree to which an individual judges the overall quality of his or her life as a whole in a favorable way (Diener et al. 1985). It is noteworthy that a wide range of factors such as physiological, psychological, social, spiritual and economic elements may determine well-being (Noehammer 2013). In an earlier study, Eller and Mahat (2007) showed that anxiety level, health transition, physical role, physical function and mental health may explain life satisfaction in HIV-positive women (see also Smith et al. 1998). Greeff et al. (2010) showed that perceived HIV-related stigma has significant negative impact on life satisfaction. Rzeszutek et al. (2015) showed that longer HIV infection duration may intensify PTSSs, but perceived availability of social support may be a buffer against HIV-related trauma symptoms in PLWHA. Other studies have shown that treatment adherence (Drozd et al. 2014), a web-based intervention trial in patients with chronic HIV infection (Reis et al. 2013) and optimism (Ammirati et al. 2015) may have a positive impact on SWB in PLWH.

Some authors suggest that spiritual and religious factors may contribute to high levels of satisfaction with life in PLWHA (Cotton et al. 2006). Liboro and Walsh (2015) examined the lived experiences and personal perspectives of men living with HIV/AIDS and suggested that religions such as Catholicism can promote acceptance and support for greater well-being of men living with HIV/AIDS. In particular, religiosity may manifest itself in religious beliefs or attitudes and participation in religious services or personal acts such as prayer. Positive association between religiosity and well-being in PLWHA is based on religion providing a source of social support, recovery of meaning in life and a coping mechanism (Siegel and Schrimshaw 2002; Steglitz et al. 2012). Positive religious coping (e.g., a reflection of a secure relationship with God, a belief in life's larger meaning and a sense of spiritual connectedness with others; Pargament et al. 1998) was significantly associated with positive mood and life satisfaction in PLWH (Lee et al. 2014), reduced depressive symptoms in PLWHA (Dalmida et al. 2013) and PTSSs in HIV-positive women (Brownley et al. 2015). Religiosity may also be associated with lower-HIV-risk behaviors (Shaw and El-Bassel 2014) and adherence to therapy in PLWH (Kisenyi et al. 2013).

Religious fundamentalism is not typical of any particular religion and has its manifestations across diverse religions. Most research on religious fundamentalism indicates its negative implications for the PLWH (e.g., people living with HIV and AIDS are often viewed as "sinners" and of low moral standards). Nevertheless, it should be noted that the activities of fundamentalist churches and religion organizations was an important factor in the effort to control the epidemic and to care for those affected by it (Jonsen and Stryker 
1993). In her work, Szaflarski (2013) showed the power of faith communities (esp. among African-Americans) to influence HIV-risk behaviors and attitudes toward PLWH, as well as a role of faith-based community interventions to reduce stigma and enhance HIV prevention/care.

According to Altemeyer and Hunsberger (1992, p. 118), religious fundamentalism is a cognitive process corresponding to "the belief that there is one set of religious teachings that clearly contains the fundamental, basic, intrinsic, inerrant truth about humanity and deity; that this essential truth is fundamentally opposed by forces of evil which must be vigorously fought; that this truth must be followed today according to the fundamental, unchangeable practices of the past; and that those who believe and follow these fundamental teachings have a special relationship with the deity."

To date, no empirical studies have been conducted to test the relationship between religious fundamentalism and PTSS in PLWHA. Religious fundamentalism focuses on the certainty that one's religious beliefs are correct and the belief that one has access to absolute truth. Ness and Wintrob (1980) showed that people who participated in fundamentalist religious activities were less likely to report emotional distress. Sethi and Seligman (1993) demonstrated that fundamentalist individuals were significantly more optimistic when compared to religiously moderate and liberal groups. The greater optimism of fundamentalist individuals may be entirely accounted for by the greater hope and daily influence fundamentalism engenders, along with the greater optimism of the religious services they hear. Green and Elliott (2010) suppose that the strict worldview of religious fundamentalists reduces their uncertainty and provides them with a stable, optimistic framework that helps them to understand and cope with life's difficulties. According to Hood et al. (2005), religious fundamentalism is a way of coping, understood as a search for meaning that helps fundamentalists meet several personal needs for meaning, such as purpose, value, efficacy and self-worth in stressful situations.

Although AbdAleati et al. (2016) suggest that religiousness may serve as a protective factor for physical and mental health, religious fundamentalism is not recognized as a factor directly associated with human health. However, Asp et al. (2012) found that patients with bilateral damage to the ventromedial prefrontal cortex reported significantly high level of religious fundamentalism. In another study, Phillips and Ano (2015) showed that religious fundamentalism is associated with a number of coping strategies that facilitate adjustment to stressful situations, such as illness. Błażek and Besta (2012) demonstrated that religious fundamentalism is highly correlated with intrinsic religiosity. It has been shown (Hui and Coleman 2013; Sanders et al. 2015) that intrinsic religiousness is inversely correlated with depression and anxiety, including death anxiety in older people. Moreover, it was shown that intrinsic religiosity is a modest protective factor against death anxiety among PLWHA (Miller et al. 2012) and decreases PTSS in people exposed to terror (Laufer and Solomon 2011). In turn, Aydin et al. (2010) showed that socially excluded individuals report significantly higher levels of religious affiliation and stronger intentions to engage in religious behaviors compared to non-excluded individuals. This result suggests that stigmatized and traumatized HIV-positive persons may also exacerbate the attitude of religious fundamentalism when trauma arises.

Several authors found that people suffering from lifetime trauma (Krause 2004; Triplett et al. 2012), having PTSD symptoms (Besser and Neria 2009; Karatzias et al. 2013), suffering from a traumatically acquired disability (Hernandez et al. 2014) or perceiving severe stress (Kaya et al. 2015) generally experience less satisfaction with life. Only a few studies refer to the relationship between religious fundamentalism and life satisfaction. Some data suggest that religious fundamentalism has a weak positive correlation with life 
satisfaction in Catholic undergraduate students (Carlucci et al. 2015) and South African social science students, their family members and friends (Nell 2014).

The aim of this study was to investigate the relationships between religious fundamentalism, satisfaction with life and PTSS in PLWHA. Taking into account the aforementioned findings, we hypothesized that: (a) religious fundamentalism would be negatively correlated with the PTSS; (b) satisfaction with life would be negatively correlated with PTSS; and (c) religious fundamentalism would be positively correlated with satisfaction with life.

\section{Method}

\section{Participants}

The sample consisted of 283 adults ( 250 men and 33 women) with a clinical diagnosis of HIV infection. Participants' ages ranged from 20 to $74(M=38.72$; SD =9.39). There were 242 patients with a clinical diagnosis of HIV positive and 41 individuals with AIDS. All individuals were treated at the Warsaw's Hospital for Infectious Disease. The duration of the HIV infection in the entire sample ranged from 1 to 33 years $(M=7.90 ; \mathrm{SD}=7.05)$. In the studied group, 123 participants had higher education, 99 participants had secondary education, and 61 participants had primary education. Participants were recruited directly by the psychologists who conducted the study. All self-report questionnaires were administered in a standard manner.

The study was anonymous, and participation was voluntary. Informed consent was obtained from all patients before they were included in the study, and participants were not remunerated.

\section{Measures}

The quantitative level of trauma symptoms was assessed with the PTSD Factorial Version Inventory (PTSDF) (Strelau et al. 2002). The PTSDF has 30 items. Patients were asked to report how often in the past several months they experienced a given thought, behavior or emotion related to the traumatic event. Participants gave answers by selecting one of four options: never, rarely, often and always. The total score was calculated as a sum of answers to all 30 items, scoring from 0 to 3 points. This questionnaire has two subscales corresponding to two basic PTSD factors (American Psychiatric Association 1994): intrusion/ arousal (Cronbach's alpha $=0.95$ ) and avoidance/numbing (Cronbach's alpha $=0.93$ ). Both subscales are highly correlated with each other $(r=0.81)$. Scores on each subscale were added to calculate the general intensity of trauma symptoms (general scale: Cronbach's alpha $=0.96$ ). All Cronbach's alphas given in parentheses are derived from the present sample of HIV-positive individuals. All analyses in the reported studies were based on the total score of the PTSDF inventory. Higher scores in the PTSDF general scale indicate higher levels of PTSSs.

Religious fundamentalism was assessed with the 20-item religious fundamentalism scale (RFS) (Altemeyer and Hunsberger 1992; Polish adaptation, Tomasz Besta and Magdalena Błażek). The scale measures religious fundamentalism understood in terms of a structure of religious attitudes. Each item is rated on an anchored scale from - 4 (very strong disagreement) to +4 (very strong agreement). The higher the score, the higher the 
religious fundamentalism. Cronbach's alpha coefficient for the Polish version of the RFS in the present sample was 0.89 .

The participants' satisfaction with life was measured using the Satisfaction with Life Scale (SWLS) (Diener et al. 1985; Polish adaptation, Zygfryd Juczyński). The SWLS has five items. Respondents indicate the degree of agreement with each item on a 7-point scale ranging from 1 (strongly disagree) to 7 (strongly agree). Thus, a higher total score on this scale indicates greater satisfaction. Cronbach's alpha coefficient for the Polish version of the SWLS in the present sample was 0.89 .

\section{Statistical Analysis}

The statistical analysis was performed with IBM SPSS Statistics 22 (IBM Corp. 2013). Descriptive statistics such as the means and standard deviations of the main variables are reported. Since the compared groups were not equinumerous, the Mann-Whitney $U$ test was used to test the significance of differences between HIV-positive and HIV/AIDS patients. Relationships among variables were examined with the Pearson product-moment coefficients.

Validity of religious fundamentalism and satisfaction with life as predictors of trauma intensity was estimated by means of multiple regression analysis.

\section{Results}

Table 1 shows the means and standard deviations for age, trauma-related symptoms intensity, religious fundamentalism and satisfaction with life separately for HIV-positive and HIV/AIDS patients. The two groups were compared using the Mann-Whitney $U$ test. Compared with HIV-positive individuals, HIV/AIDS patients had significantly lower levels of satisfaction with life.

Table 2 presents the correlations among age, trauma symptom intensity, religious fundamentalism and satisfaction with life in the whole sample. Positive correlations were found for religious fundamentalism and age as well as religious fundamentalism and trauma symptoms intensity. Negative correlation between satisfaction with life and trauma symptom intensity was also found.

To determine the extent to which religious fundamentalism and satisfaction with life can be viewed as predictors of the trauma symptoms intensity (treated as the explained

Table 1 Mean and standard deviation comparisons for age, trauma symptom intensity, religious fundamentalism and satisfaction with life in PLWH $(n=242)$ and PLWHA $(n=41)$

\begin{tabular}{llllr}
\hline Variables & $\begin{array}{l}\text { PLWH } \\
M(\mathrm{SD})\end{array}$ & $\begin{array}{l}\text { PLWHA } \\
M(\mathrm{SD})\end{array}$ & $Z$ & Cohen's $d$ \\
\hline Age & $38.29(9.32)$ & $41.29(9.55)$ & -1.95 & -0.32 \\
Trauma symptom intensity & $58.76(19.49)$ & $60.28(17.74)$ & -0.66 & -0.08 \\
Religious fundamentalism & $78.93(28.51)$ & $72.60(28.72)$ & -1.09 & 0.22 \\
Satisfaction with life & $18.72(6.93)$ & $15.24(7.72)$ & $-2.95^{* *}$ & 0.47 \\
\hline
\end{tabular}

$Z=$ value for the Mann-Whitney $U$ test

$* * p<0.01$ 
Table 2 Pearson's $r$ correlations among age, HIV infection duration, trauma symptom intensity, religious fundamentalism and satisfaction with life in the whole sample $(n=283)$

\begin{tabular}{llll}
\hline & Trauma intensity & Religious fundamentalism & Satisfaction with life \\
\hline Age & 0.04 & $0.12^{*}$ & -0.01 \\
Trauma symptom intensity & & $0.25^{* *}$ & $-0.56^{* *}$ \\
Religious fundamentalism & & & -0.07 \\
\hline
\end{tabular}

$* p<0.05 ; * * p<0.01$

variable in the analysis) among participants, we conducted a multiple regression analysis. The results are shown in Table 3.

As shown in Table 3, the religious fundamentalism explained $4 \%$ and satisfaction with life explained $30 \%$ of the global trauma symptoms. Together these two variables accounted for $34 \%$ of the variance of the global trauma symptoms.

The additional ad hoc assumption was that the education level would mediate the relationship between the religious fundamentalism and the global trauma score among participants (see, for example, Schwadel 2016). Three separate regression analyses were conducted following the Baron and Kenny approach (1986). To assess for mediation, the Sobel test for mediation was performed. The results showed that education level was a significant, partial mediator of the relationship between the religious fundamentalism and the global trauma score (Sobel test values: $Z=2.563, p=0.0010$ ). These results are presented in Fig. 1.

The mediation analysis (see Fig. 1) revealed that the total effect between the religious fundamentalism and the global trauma score $(\beta=0.25, p<0.001)$ was reduced upon the inclusion of the mediator-participants' educational level $(\beta=0.20, p<0.01)$.

\section{Discussion}

The aim of this study was to investigate the relationships among religious fundamentalism, satisfaction with life PTSSs and PTSSs in PLWHA.

Religious fundamentalism was weakly positively associated with PTSSs (see Table 2). It seems that increase in PTSSs level is conducive to intensification of fundamentalist religious attitudes, which are related to religious behavior. The result is surprising, as we assumed that religious fundamentalism will be negatively correlated with PTSSs, as many other studies suggested (Hood et al. 2005; Ness and Wintrob 1980; Phillips and Ano 2015).

Table 3 Multiple regression analysis of religious fundamentalism and satisfaction with life as predictors of trauma symptom intensity in PLWHA $(n=283)$

\begin{tabular}{lrccc}
\hline Variable & \multicolumn{1}{c}{$B$} & SE $B$ & $\beta$ & Semi-partial correlations \\
\hline Religious fundamentalism & 0.14 & 0.03 & $0.21^{* * *}$ & 0.20 \\
Satisfaction with life & -1.48 & 0.13 & $-0.55^{* * *}$ & -0.55 \\
\hline
\end{tabular}

$S E$ standard error

$* * * p<0.001$ 


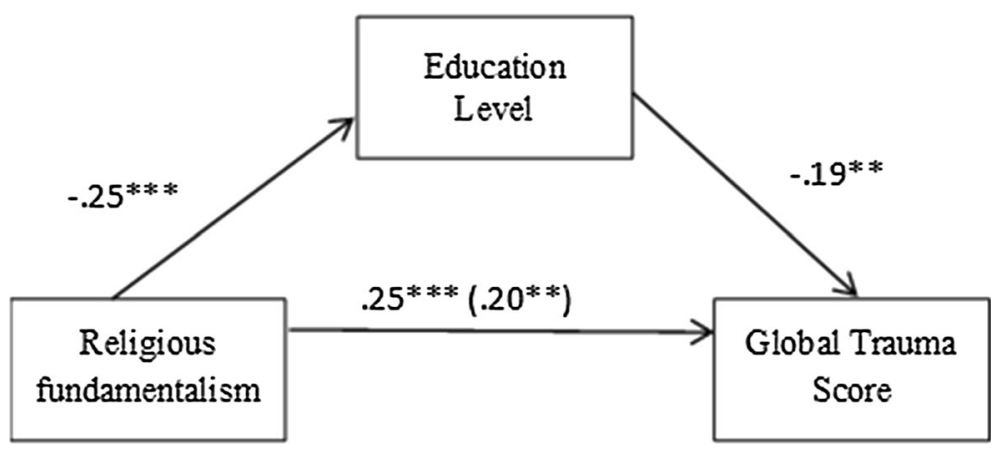

Fig. 1 Relationship between religious fundamentalism and the global trauma score as mediated by education level among participants. Note $* * * p<.001 ; * * p<.01$

In addition, several authors proved that HIV + persons rarely return to religion as a form of coping with HIV-related trauma. In particular, Wanyama et al. (2007) showed that religious beliefs about HIV may cause fatalistic attitudes and resignation from treatment. Furthermore, Zou et al. (2009) proved that moral connotations usually associated with HIV infection can turn the religious community into a stigmatizing atmosphere for PLWH, which can lead them to withdraw from such a community. Mediation analysis revealed that relationship between religious fundamentalism and the PTSSs intensity was mediated by education level among participants. The higher the education, the lower the relationship between religious fundamentalism and the PTSSs intensity. Therefore, in the future investigation, it is necessary to verify the role of the education in religious fundamentalism-PTSSs relationship.

As noted above, religious coping may be related with positive mood and life satisfaction among PLWH (Lee et al. 2014) and may reduce depressive symptoms in PLWHA (Dalmida et al. 2013) and PTSSs in HIV-positive women (Brownley et al. 2015). On the other hand, Weber et al. (2012) showed that non-believers may experience psychological distress because of others' negative perceptions. Returning to belief in the literal truth of the Bible and in the existence of a single, infallible set of religious truths may contribute to increasing subjective well-being and decreasing psychological distress related to HIV/ AIDS infection. According to Carlucci et al. (2015), people who score high on religious fundamentalism scales tend to use religion to gain comfort, security and/or protection. Thus, anxiety, depression and PTSSs can motivate PLWHA to seek support in religion and strengthen their fundamentalist religious attitudes (Cotton et al. 2006). In terms of social stigma, turning to religion can be a powerful coping response when dealing with social rejection (Aydin et al. 2010). Compared with that of other European countries, religiousness in Poland is typically accompanied by a stable and relatively strong attachment to religious practices, such as church services, masses or encounters. According to the Public Opinion Research Centre (CBOS 2015), nearly 92\% of all Poles declare that they are believers, and $87 \%$ of them are practicing religion. The hypothesis about increasing religious fundamentalism is being a way to reduce HIV-related trauma may be strongly supported in the Polish sample because of culturally inherited Catholicism, a strong attachment to own religion and the number of religious believers living in Poland. This hypothesis was not confirmed.

The results of the study show that satisfaction with life is negatively associated with PTSSs (see Table 2). The higher the PTSSs, the lower the life satisfaction in PLWHA. 
Satisfaction with life accounted for $30 \%$ of the variance of the trauma symptom intensity in PLWHA (see Table 3). Some major sources of this relationship may include PLWHA still experiencing social stigmatization that causes negative attitudes toward HIV-positive people and fear of contagion (Drewes and Kleiber 2014) and discrimination by families members (Adewuya et al. 2009; Gilbert and Walker 2010) and health professionals (Valenzuela et al. 2015). In other study, Cama et al. (2015) showed that PLWH appear to experience greater stigma related to taking HIV treatment than general stigma associated with HIV. HIV-related stigmatization seems to be a significant source of poor life satisfaction in PLWHA (Buseh et al. 2006; Heckman 2003). Other factors such as a lifethreatening HIV infection and the unpredictable course of HIV/AIDS development may also lead to the occurrence of depression, anxiety and PTSSs among PLWHA (Lowther et al. 2014; Theuninck et al. 2010) and death anxiety following the PTSSs (Galinha and Pais-Ribeiro 2011; Routledge et al. 2010; Safren et al. 2003). On the other hand, Miller et al. (2012) showed that as the time since HIV diagnosis increased, PLWHA experienced less death anxiety.

Although satisfaction with life has a direct relationship with PTSSs, the connection between religious fundamentalism and satisfaction with life has not been confirmed. Religious fundamentalism may be found to be directly associated with trauma but not with satisfaction with life. Although Nell (2014) found no direct effect between religious fundamentalism and life satisfaction in his study, he did find a significant indirect effect in which the presence of life meaning mediated the relationship between religious fundamentalism and life satisfaction. This finding suggests that the relationship between religious fundamentalism and life satisfaction is indirect. A high level of fundamentalism, associated with clear and definite beliefs in an absolute truth, may lead believers to develop a meaning for life, which in turn enhances their life satisfaction. This result suggests the need to seek mediators between religious fundamentalism and satisfaction with life, especially in the elderly, who are more fundamentally religious, as indicated by the weak positive correlation between age and fundamentalism in the studied group (see Table 2).

The HIV/AIDS group experiences significantly lower life satisfaction compared with the HIV-positives but without AIDS (see Table 1). One of the reasons for this difference may be long-lasting infection in PLWHA group and the associated long-lasting psychological distress. However, the groups did not differ in PTSS level or the level of religious fundamentalism. The differences in the trauma symptom intensity between the two groups were also not demonstrated in an earlier study (Rzeszutek et al. 2012).

This study is not free of limitations. The study's cross-sectional design does not allow for inferences about causation and the direction of causality. The sample was differentiated in terms of age, sex and phase of HIV infection development (HIV positive vs. HIV/ AIDS). It does not include information about the possibility of previous traumatic events in participants' lives that could have an impact on PTSS levels and assessment of satisfaction with life by PLWHA. The results suggest that future research should take into account not only religious fundamentalism but also the significance of social surroundings.

Despite these limitations, the results of this study provide a knowledge about the relationship between the PTSSs and satisfaction with life in PLWHA and may be a source of inspiration for further investigation and analysis referring to the relationship between religious fundamentalism and life satisfaction, taking mediating factors into an account.

Acknowledgements This work was supported by the University of Warsaw, Faculty of Psychology under Grant BST 1712-10 2014. The authors thank Magdalena Żebrowska for her research assistance. 


\section{Compliance with Ethical Standards}

Conflict of interest The authors declare that they have no conflict of interest.

Human and Animal Rights All procedures performed in studies involving human participants were in accordance with the ethical standards of the institution or practice at which the studies were conducted. The research project was accepted by the local Ethics Commission at the Faculty of Psychology, University of Warsaw. This article does not contain any studies with animals performed by any of the authors.

Informed Consent Informed consent was obtained from all participants before they were included in the study.

Open Access This article is distributed under the terms of the Creative Commons Attribution 4.0 International License (http://creativecommons.org/licenses/by/4.0/), which permits unrestricted use, distribution, and reproduction in any medium, provided you give appropriate credit to the original author(s) and the source, provide a link to the Creative Commons license, and indicate if changes were made.

\section{References}

AbdAleati, N. S., Mohd Zaharim, N., \& Mydin, Y. O. (2016). Religiousness and mental health: Systematic review study. Journal of Religion and Health, 55, 1929-1937. https://doi.org/10.1007/s10943-0149896-1.

Adewuya, A., Afolabi, M., Ola, B., Ogundele, O., Ajibare, A., Oladipo, B., et al. (2009). Post-traumatic stress disorder (PTSD) after stigma related events in HIV infected individuals in Nigeria. Social Psychiatry and Psychiatric Epidemiology, 44, 761-766. https://doi.org/10.1007/s00127-009-0493-7.

Altemeyer, B., \& Hunsberger, B. (1992). Authoritarianism, religious fundamentalism, quest, and prejudice. The International Journal for the Psychology of Religion, 2, 113-133. https://doi.org/10.1207/ s15327582ijpr0202_5.

American Psychiatric Association. (1994). Diagnostic and statistical manual of mental disorders (4th ed.). Washington, DC: American Psychiatric Association.

Ammirati, R. J., Lamis, D. A., Campos, P. E., \& Farber, E. W. (2015). Optimism, well-being, and perceived stigma in individuals living with HIV. AIDS Care, 27, 926-933. https://doi.org/10.1080/09540121. 2015.1018863

Asp, E., Ramchandran, K., \& Tranel, D. (2012). Authoritarianism, religious fundamentalism, and the human prefrontal cortex. Neuropsychology, 26, 414-421. https://doi.org/10.1037/a0028526.

Aydin, N., Fischer, P., \& Frey, D. (2010). Turning to God in the face of ostracism: Effects of social exclusion on religiousness. Personality and Social Psychology Bulletin, 36, 742-753. https://doi.org/ $10.1177 / 0146167210367491$.

Barroso, J., Hammill, B. G., Leserman, J., Salahuddin, N., Harmon, J. L., \& Pence, B. W. (2010). Physiological and psychosocial factors that predict HIV-related fatigue. AIDS and Behavior, 14, 1415-1427. https://doi.org/10.1007/s10461-010-9691-2.

Besser, A., \& Neria, Y. (2009). PTSD symptoms, satisfaction with life, and prejudicial attitudes toward the adversary among Israeli civilians exposed to ongoing missile attacks. Journal of Traumatic Stress, 22, 268-275. https://doi.org/10.1002/jts.20420.

Błażek, M., \& Besta, T. (2012). Self-concept clarity and religious orientations: Prediction of purpose in life and self-esteem. Journal of Religion and Health, 51, 947-960. https://doi.org/10.1007/s10943-0109407-y.

Bogart, L. M., Wagner, G. J., Galvan, F. H., Landrine, H., Klein, D. J., \& Sticklor, L. A. (2011). Perceived discrimination and mental health symptoms among Black men with HIV. Cultural Diversity and Ethnic Minority Psychology, 17, 295-302. https://doi.org/10.1037/a0024056.

Breet, E., Kagee, A., \& Seedat, S. (2014). HIV-related stigma and symptoms of post-traumatic stress disorder and depression in HIV-infected individuals: Does social support play a mediating or moderating role? AIDS Care, 26, 947-951. https://doi.org/10.1080/09540121.2014.901486.

Brownley, J. R., Fallot, R. D., Berley, R. W., \& Himelhoch, S. S. (2015). Trauma history in AfricanAmerican women living with HIV: Effects on psychiatric symptom severity and religious coping. AIDS Care, 27, 964-971. https://doi.org/10.1080/09540121.2015.1017441.

Buseh, A. G., Kelber, S. T., Hewitt, J. B., Stevens, P. E., \& Park, C. G. (2006). Perceived stigma and life satisfaction: Experiences of urban African American men living with HIV/AIDS. International Journal of Men's Health, 5, 35-51. https://doi.org/10.3149/jmh.0501.35. 
Cama, E., Brener, L., Slavin, S., \& de Wit, J. (2015). The impact of HIV treatment-related stigma on uptake of antiretroviral therapy. AIDS Care, 27, 739-742. https://doi.org/10.1080/09540121.2014.998614.

Carlucci, L., Tommasi, M., Balsamo, M., Furnham, A., \& Saggino, A. (2015). Religious fundamentalism and psychological well-being: An Italian study. Journal of Psychology and Theology, 43(1), 23-33.

CBOS. (2015). Zmiany w zakresie podstawowych wskaźników religijności Polaków po śmierci Jana Pawła II [Changes in the basic indicators of religiosity Poles after the death of John Paul II]. Warszawa: Centrum Badania Opinii Społecznej.

Chander, G., Himelhoch, S., \& Moore, R. G. (2006). Substance abuse and psychiatric disorders in HIVpositive patients. Drugs, 66, 769-789. https://doi.org/10.2165/00003495-200666060-00004.

Cotton, S., Puchalski, C. M., Sherman, S. N., Mrus, J. M., Peterman, A. H., Feinberg, J., et al. (2006). Spirituality and religion in patients with HIV/AIDS. Journal of General Internal Medicine, 21, S5S13. https://doi.org/10.1111/j.1525-1497.2006.00642.x.

Dalmida, S. G., Koenig, H. G., Holstad, M. M., \& Wirani, M. M. (2013). The psychological well-being of people living with HIV/AIDS and the role of religious coping and social support. International Journal of Psychiatry in Medicine, 46, 57-83. https://doi.org/10.2190/PM.46.1.e.

Deeks, S. G., Lewin, S. R., \& Havlir, D. V. (2013). The end of AIDS: HIV infection as a chronic disease. Lancet, 382, 1525-1533. https://doi.org/10.1016/S0140-6736(13)61809-7.

Diener, E., Emmons, R. A., Larsen, R. J., \& Griffin, S. (1985). The satisfaction with life scale. Journal of Personality Assessment, 49, 71-75. https://doi.org/10.1207/s15327752jpa4901_13.

Drewes, J., \& Kleiber, D. (2014). Contagiousness under antiretroviral therapy and stigmatization toward people with HIV. AIDS Care, 26, 1383-1386. https://doi.org/10.1080/09540121.2014.913768.

Drozd, F., Skeie, L. G., Kraft, P., \& Kvale, D. (2014). A web-based intervention trial for depressive symptoms and subjective well-being in patients with chronic HIV infection. AIDS Care, 26, 1080-1089. https://doi.org/10.1080/09540121.2013.869541.

Eller, L. S., \& Mahat, G. (2007). Predictors of life satisfaction in HIV-positive Nepali women. Journal of the Association of Nurses in AIDS Care, 18, 17-26. https://doi.org/10.1016/j.jana.2007.07.002.

Galinha, I., \& Pais-Ribeiro, J. L. (2011). Cognitive, affective and contextual predictors of subjective wellbeing. International Journal of Wellbeing, 2, 34-53. https://doi.org/10.5502/ijw.v2i1.3.

Gilbert, L., \& Walker, L. (2010). 'My biggest fear was that people would reject me once they knew my status': Stigma as experienced by patients in an HIV/AIDS clinic in Johannesburg, South Africa. Health and Social Care in the Community, 18, 139-146. https://doi.org/10.1111/j.1365-2524.2009. 00881.x.

Greeff, M., Uys, L. R., Wantland, D., Makoae, L., Chirwa, M., Dlamini, P., et al. (2010). Perceived HIV stigma and life satisfaction among persons living with HIV infection in five African countries: A longitudinal study. International Journal of Nursing Studies, 47, 475-486. https://doi.org/10.1016/j. ijnurstu.2009.09.008.

Green, M., \& Elliott, M. (2010). Religion, health, and psychological well-being. Journal of Religion and Health, 49, 149-163. https://doi.org/10.1007/s10943-009-9242-1.

Heckman, T. G. (2003). The chronic illness quality of life (CIQOL) model: Explaining life satisfaction in people living with HIV disease. Health Psychology, 22, 140-147. https://doi.org/10.1037/0278-6133. 22.2.140.

Hernandez, C. L., Elliott, T. R., Berry, J. W., Underhill, A. T., Fine, P. R., \& Lai, M. H. C. (2014). Trajectories of life satisfaction 5 years after medical discharge for traumatically acquired disability. Rehabilitation Psychology, 59, 183-192. https://doi.org/10.1037/a0035887.

Hood, R. W., Jr., Hill, P. C., \& Williamson, W. P. (2005). The psychology of religious fundamentalism. New York: Guilford Press.

Hui, V. K.-Y., \& Coleman, P. G. (2013). Afterlife beliefs and ego integrity as two mediators of the relationship between intrinsic religiosity and personal death anxiety among older adult British Christians. Research on Aging, 35, 144-162. https://doi.org/10.1177/0164027512436429.

IBM Corp. (2013). IBM SPSS statistics for windows, version 22.0. Armonk, NY: IBM Corp.

Jonsen, A. R., \& Stryker, J. (Eds.). (1993). The social impact of AIDS in the United States. Washington, DC: National Academies Press.

Karatzias, T., Chouliara, Z., Power, K., Brown, K., Begum, M., McGoldrick, T., et al. (2013). Life satisfaction in people with post-traumatic stress disorder. Journal of Mental Health, 22, 501-508. https:// doi.org/10.3109/09638237.2013.819418.

Kaya, C., Tansey, T. N., Melekoğlu, M., \& Çakıroğlu, O. (2015). Stress and life satisfaction of Turkish college students. College Student Journal, 49(2), 257-261.

Kee, M.-K., Lee, S.-Y., Kim, N.-Y., Lee, J.-S., Kim, J. M., Choi, J. Y., et al. (2015). Anxiety and depressive symptoms among patients infected with human immunodeficiency virus in South Korea. AIDS Care, 27, 1174-1182. https://doi.org/10.1080/09540121.2015.1035861. 
Kisenyi, R. N., Muliira, J. K., \& Ayebare, E. (2013). Religiosity and adherence to antiretroviral therapy among patients attending a public hospital-based HIV/AIDS clinic in Uganda. Journal of Religion and Health, 52, 307-317. https://doi.org/10.1007/s10943-011-9473-9.

Krause, N. (2004). Lifetime trauma, emotional support, and life satisfaction among older adults. The Gerontologist, 44, 615-623. https://doi.org/10.1093/geront/44.5.615.

Laufer, A., \& Solomon, Z. (2011). The role of religious orientations in youth's posttraumatic symptoms after exposure to terror. Journal of Religion and Health, 50, 687-699. https://doi.org/10.1007/s10943-0099270-x.

Lee, M., Nezu, A. M., \& Nezu, C. M. (2014). Positive and negative religious coping, depressive symptoms, and quality of life in people with HIV. Journal of Behavioral Medicine, 37, 921-930. https://doi.org/ 10.1007/s10865-014-9552-y.

LeGrand, S., Reif, S., Sullivan, K., Murray, K., Barlow, M. L., \& Whetten, K. (2015). A review of recent literature on trauma among individuals living with HIV. Current HIV/AIDS Reports, 12, 397-405. https://doi.org/10.1007/s11904-015-0288-2.

Leyro, T. M., Babson, K. A., \& Bonn-Miller, M. O. (2014). Anxiety sensitivity in relation to sleep quality among HIV-infected individuals. Journal of the Association of Nurses in AIDS Care, 25, 638-645. https://doi.org/10.1016/j.jana.2014.02.002.

Liboro, R. M., \& Walsh, R. T. G. (2015). Understanding the irony: Canadian gay men living with HIV/ AIDS, their Catholic devotion, and greater well-being. Journal of Religion and Health, 55, 650-670. https://doi.org/10.1007/s10943-015-0087-5.

Logie, C., \& Gadalla, T. M. (2009). Meta-analysis of health and demographic correlates of stigma towards people living with HIV. AIDS Care, 21, 742-753. https://doi.org/10.1080/09540120802511877.

Lowther, K., Selman, L., Harding, R., \& Higginson, I. J. (2014). Experience of persistent psychological symptoms and perceived stigma among people with HIV on antiretroviral therapy (ART): A systematic review. International Journal of Nursing Studies, 51, 1171-1189. https://doi.org/10.1016/j.ijnurstu. 2014.01.015.

Martin, L., \& Kagee, A. (2011). Lifetime and HIV-related PTSD among persons recently diagnosed with HIV. AIDS and Behavior, 15, 125-131. https://doi.org/10.1007/s10461-008-9498-6.

Miller, A. K., Lee, B. L., \& Henderson, C. E. (2012). Death anxiety in persons with HIV/AIDS: A systematic review and meta-analysis. Death Studies, 36, 640-663. https://doi.org/10.1080/07481187. 2011.604467.

Nell, W. (2014). Exploring the relationship between religious fundamentalism, life satisfaction, and meaning in life. Journal of Psychology in Africa, 24, 159-166. https://doi.org/10.1080/14330237.2014. 903074.

Ness, R. C., \& Wintrob, R. M. (1980). The emotional impact of fundamentalist religious participation. American Journal of Orthopsychiatry, 50, 302-315. https://doi.org/10.1111/j.1939-0025.1980.tb03292. $\mathrm{x}$.

Noehammer, E. (Ed.). (2013). Psychology of well-being: Theory, perspectives and practice. Hauppauge, NY: Nova Science Publishers.

Oberjé, E. J. M., Dima, A. L., van Hulzen, A. G. W., Prins, J. M., \& de Bruin, M. (2015). Looking beyond health-related quality of life: Predictors of subjective well-being among people living with HIV in the Netherlands. AIDS and Behavior, 19, 1398-1407. https://doi.org/10.1007/s10461-014-0880-2.

Pargament, K., Smith, B., Koenig, H., \& Perez, L. (1998). Patterns of positive and negative religious coping with major life stressors. Journal for the Scientific Study of Religion, 37, 710-724. https://doi.org/10. $2307 / 1388152$.

Phillips, R. E., \& Ano, G. G. (2015). A re-examination of religious fundamentalism: Positive implications for coping. Mental Health, Religion \& Culture, 18, 299-311. https://doi.org/10.1080/13674676.2015. 1022521.

Reis, A. C., Guerra, M. N., \& Lencastre, L. M. (2013). Treatment adherence and subjective well-being in HIV/AIDS infection. AIDS Care, 25, 1604-1611. https://doi.org/10.1080/09540121.2013.793276.

Robertson, K., Bayon, C., Molina, J.-M., McNamara, P., Resch, C., Muñoz-Moreno, J. A., et al. (2014). Screening for neurocognitive impairment, depression, and anxiety in HIV-infected patients in Western Europe and Canada. AIDS Care, 26, 1555-1561. https://doi.org/10.1080/09540121.2014.936813.

Routledge, C., Ostafin, B., Juhl, J., Sedikides, C., Cathey, C., \& Liao, J. (2010). Adjusting to death: The effects of mortality salience and self-esteem on psychological well-being, growth motivation, and maladaptive behavior. Journal of Personality and Social Psychology, 99, 897-916. https://doi.org/10. 1037/a0021431.

Rzeszutek, M., Oniszczenko, W., \& Firląg-Burkacka, E. (2012). Temperament traits, coping style and trauma symptoms in HIV+ men and women. AIDS Care, 24, 1150-1154. https://doi.org/10.1080/ 09540121.2012.687819. 
Rzeszutek, M., Oniszczenko, W., Żebrowska, M., \& Firląg-Burkacka, E. (2015). HIV infection duration, social support and the level of trauma symptoms in a sample of HIV positives Polish individuals. AIDS Care: Psychological, and Socio-medical Aspects of AIDS/HIV, 27, 363-369. https://doi.org/10.1080/ 09540121.2014.963018.

Safren, S. A., Gershuny, B. S., \& Hendriksen, E. (2003). Symptoms of posttraumatic stress and death anxiety in persons with HIV and medication adherence difficulties. AIDS Patient Care STDs, 17, 657-664. https://doi.org/10.1089/108729103771928717.

Sanders, P. W., Allen, G. E. K., Fischer, L., Richards, P. S., Morgan, D. T., \& Potts, R. W. (2015). Intrinsic religiousness and spirituality as predictors of mental health and positive psychological functioning in Latter-day Saint adolescents and young adults. Journal of Religion and Health, 54, 871-887. https:// doi.org/10.1007/s10943-015-0043-4.

Schwadel, P. (2016). Does higher education cause religious decline? A longitudinal analysis of the withinand between-person effects of higher education on religiosity. The Sociological Quarterly, 57, 759-786. https://doi.org/10.1111/tsq.12153.

Sethi, S., \& Seligman, M. E. P. (1993). Optimism and fundamentalism. Psychological Science, 4, $256-259$. https://doi.org/10.1111/j.1467-9280.1993.tb00271.x.

Shaw, S. A., \& El-Bassel, N. (2014). The influence of religion on sexual HIV risk. AIDS and Behavior, 18, 1569-1594. https://doi.org/10.1007/s10461-014-0714-2.

Siegel, K., \& Schrimshaw, E. W. (2002). The perceived benefits of religious and spiritual coping among older adults living with HIV/AIDS. Journal for the Scientific Study of Religion, 41, 91-102. https://doi. org/10.1111/1468-5906.00103.

Slater, L. Z., Moneyham, L., Vance, D. E., Raper, J. L., Mugavero, M. J., \& Childs, G. (2015). The multiple stigma experience and quality of life in older gay men with HIV. Journal of the Association of Nurses in AIDS Care, 26, 24-35. https://doi.org/10.1016/j.jana.2014.06.007.

Smith, K. W., Avis, N. E., \& Assmann, S. F. (1998). Distinguishing between quality of life and health status in quality of life research: A meta-analysis. Quality of Life Research, 8, 447-459. https://doi.org/10. 1023/A: 1008928518577.

Steglitz, J., Ng, R., Mosha, J. S., \& Kershaw, T. (2012). Divinity and distress: The impact of religion and spirituality on the mental health of HIV-positive adults in Tanzania. AIDS and Behavior, 16, 2392-2398. https://doi.org/10.1007/s10461-012-0261-7.

Strelau, J., Zawadzki, B., Oniszczenko, W., \& Sobolewski, A. (2002). Kwestionariusz PTSD—wersja czynnikowa (PTSD-C): Konstrukcja narzędzia do diagnozy głównych wymiarów zespołu stresu pourazowego [The PSTD Factorial Version: Construction of a tool to diagnose the main dimensions of post-traumatic stress disorder]. Przeglad Psychologiczny, 45(2), 149-176.

Szaflarski, M. (2013). Spirituality and religion among HIV-infected individuals. Current HIV/AIDS Report, 10, 324-332. https://doi.org/10.1007/s11904-013-0175-7.

Theuninck, A., Lake, N., \& Gibson, S. (2010). HIV-related posttraumatic stress disorder: Investigating the traumatic events. AIDS Patient Care and STDs, 24, 458-491. https://doi.org/10.1089/apc.2009.0231.

Triplett, K. N., Tedeschi, R. G., Cann, A., Calhoun, L. G., \& Reeve, C. L. (2012). Posttraumatic growth, meaning in life, and life satisfaction in response to trauma. Psychological Trauma: Theory, Research, Practice, and Policy, 4, 400-410. https://doi.org/10.1037/a0024204.

Valenzuela, C., Ugarte-Gil, C., Paz, J., Echevarria, J., Gotuzzo, E., Vermund, S. H., et al. (2015). HIV stigma as a barrier to retention in HIV care at a general hospital in Lima, Peru: A case-control study. AIDS and Behavior, 19, 235-245. https://doi.org/10.1007/s10461-014-0908-7.

Wanyama, J., Castelnuovo, B., Wandera, B., Mwebaze, P., Kambugu, A., Bangsberg, D., et al. (2007). Belief in divine healing can be a barrier to antiretroviral therapy adherence in Uganda. AIDS, 11, 1486-1487. https://doi.org/10.1097/QAD.0b013e32823ecf7f.

Weber, S. R., Pargament, K. I., Kunik, M. E., Lomax, J. W., \& Stanley, M. A. (2012). Psychological distress among religious nonbelievers: A systematic review. Journal of Religion and Health, 51, 72-86. https:// doi.org/10.1007/s10943-011-9541-1.

Ye, Z., Chen, L., Guo, W., \& Lin, D. (2015). Perceived stigma and PTSD among HIV-positive MSM in China: The mediating effect of coping strategies. Chinese Journal of Clinical Psychology, 23(1), 76-79.

Zou, J., Yamanaka, Y., John, M., Watt, M., Ostermann, J., \& Thielman, N. (2009). Religion and HIV in Tanzania: Influence of religious beliefs on HIV stigma, disclosure, and treatment attitudes. BMC Public Health, 9, 75. https://doi.org/10.1186/1471-2458-9-75. 